\title{
Generation of Drug Metabolite Antigenicity in the Intestinal Mucosa
}

\author{
Chung Wu and Kenneth P. Mathews \\ Department of Biological Chemistry and Montgomery Allergy Research Laboratory, Department of Internal Medicine, The University \\ of Michigan Medical School, Ann Arbor, MI 48109, U.S.A.
}

(Received 20 November 1985; accepted 27 March 1986)

\begin{abstract}
Both nitroreductase and transglutaminase activities have been assayed in the $10000 \times g$ supernatant fluids of rat intestine homogenates after Triton X-100 treatment. Incubation of ${ }^{14} \mathrm{C}$-nitrofurantoin in the intestine extract yielded protein-bound ${ }^{14} \mathrm{C}$-labeled products. Injection into rabbits of the conjugated protein similarly prepared with unlabeled nitrofurantoin elicited formation of antibodies against nitrofurantoin. These results suggest that intestinal metabolism and conjugation to protein of orally administered drugs may serve as a probable mechanism of drug allergy, and this may be accomplished by enzymatic coupling of relatively stable drug metabolites to protein carriers.
\end{abstract}

Key words: Nitrofurantoin; Rat intestine; Antigenicity; Drug allergy

\section{Introduction}

Landsteiner's (1936) classical immunochemical studies demonstrated that low molecular weight compounds (which include most drugs) generally must be covalently bound to a high molecular weight carrier in order to stimulate an anti-hapten antibody response. Eisen (1959) additionally showed that the sensitizing capacity of simple organic molecules also correlated with their capacity to react with proteins in vivo. Conversely, the reversible, ionic and hydrophobic interactions of many drugs with albumin and other serum proteins are insufficient to generate an immune response (Parker, 1979). An alternative possibility is that stable drugs or drug metabolites gain antigenicity by being covalently linked to high molecular weight carriers by enzymes normally present in various tissues. This has been documented by the capacity of transglutaminases to couple isoniazid and hydral- azine to protein (Lorand et al., 1972; Buxman, 1979).

Although the evidence is largely circumstantial, it is likely that the generation of immunogenic drug hapten-protein conjugates most often occurs in the liver: it is the site of metabolism of many drugs, it is a source of several types of enzymes potentially capable of binding drug metabolites to proteins, and it is the frequent target of drug reactions which appear to have an allergic basis (as well as toxic reactions) (Parker 1980). However, a more complete understanding of pathogenetic mechanisms of drug allergy needs to take into account the possible generation of drug-related immunogenicity in other organs. Since most drugs are administered orally, the gastrointestinal tract mucosa in particular warrants assessments in this respect. For this purpose we choose to study its possible capacity to confer antigenicity on nitrofurantoin, because this drug commonly causes adverse reactions which may be 
immunologically mediated (Holmberg et al., 1980), and its metabolism has been studied (Hoener and Krueger, 1984; Moreno et al., 1984). The objective was to show whether rat intestinal walls contained enzymes that could not only reduce nitrofurantoin but also conjugate the reduction product(s) to protein and to determine whether the protein conjugate so formed was immunogenic with respect to the hapten.

\section{Materials and Methods}

Liver and intestinal walls of male adult rats of the Sprague-Dawley strain were used. Intestinal walls were prepared by removing mesenteries, cutting the walls lengthwise and rinsing in fresh portions of ice-cold $0.15 \mathrm{M} \mathrm{KCl}$ to wash away intestinal contents as much as possible. The tissues were blotted on filter paper before weighing. Tissue homogenates were made in ice-cold $0.15 \mathrm{M} \mathrm{KCl}$ containing $0.1 \%$ Triton X-100 and centrifuged at $10000 \times g$ for $25 \mathrm{~min}$ at $4^{\circ} \mathrm{C}$. The supernatant fluids were used for the experiments described below. Male New Zealand white rabbits were used for immunization.

$\left[{ }^{14} \mathrm{C}-\right.$ Methylene]-nitrofurantoin (specific activity $11.3 \mu \mathrm{Ci} / \mathrm{mg}$ ) was a gift from Norwich-Eaton Pharmaceuticals (Norwich, NY). Goat anti-rabbit immunoglobulin serum was purchased from Bio-Rad. All other chemicals were of reagent grade.

\section{Nitroreductase assay}

The incubation mixture (Aufrere et al., 1978) con-

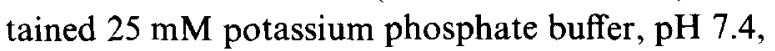
$3.8 \mathrm{mM}$ glucose-6-phosphate, $0.67 \mathrm{mM} \mathrm{MgCl}_{2}$, $0.16 \mathrm{mM}$ nitrofurantoin, $0.12 \mathrm{mM} \mathrm{NADP}^{+}$, and tissue extract containing about $20 \mathrm{mg}$ tissue in a final volume of $1 \mathrm{ml}$. Glucose-6-phosphate and $\mathrm{NADP}^{+}$were used to generate NADPH by glucose-6-phosphate dehydrogenase present in the tissue extract. NADPH was the actual reducing agent in the reduction. The mixture, in a small bottle capped with a perforable rubber stopper, was flushed with nitrogen for 2-3 min to assure anaerobic conditions. It was then incubated at $37^{\circ} \mathrm{C}$ for
0 (as control) and $20 \mathrm{~min}$. At the end of incubation, an aliquot of the reaction mixture was used for determining the amount of nitrofurantoin remaining.

The decrease in nitrofurantoin from nitroreduction was measured by a modification of the hyamine assay (Mattok et al., 1970). $0.5 \mathrm{ml}$ of the reaction mixture was extracted with $1.25 \mathrm{ml}$ of nitromethane and centrifuged at $1000 \times g$ for $15 \mathrm{~min}$. The aqueous layer was discarded. An aliquot of 830 $\mu \mathrm{l}$ of the nitromethane layer was mixed with $83 \mu \mathrm{l}$ of $3.3 \mathrm{mM}$ hyamine hydroxide. The absorbance at $400 \mathrm{~nm}$ was measured $5 \mathrm{~min}$ after the hyamine addition. The amount of nitrofurantoin remaining in the reaction mixture was estimated by means of a standard curve of nitrofurantoin following nitromethane extraction.

\section{Transglutaminase assay}

This assay was done with the procedure of Connellan et al. (1971). The reaction mixture contained $0.1 \mathrm{M}$ Tris-acetate buffer, $\mathrm{pH} 6.0,5 \mathrm{mM} \mathrm{CaCl}_{2}, 100$ $\mathrm{mM}$ hydroxylamine hydrochloride, $10 \mathrm{mM}$ glutathione, $30 \mathrm{mM}$ carbobenzoxy(CBZ)-L-glutaminylglycine, and tissue extract containing about $50 \mathrm{mg}$ tissue in a final volume of $1 \mathrm{ml}$. Incubation was done at $37^{\circ} \mathrm{C}$ for $20 \mathrm{~min}$. The control contained no CBZ-L-glutaminylglycine. At the end of incubation, $0.12 \mathrm{ml}$ of a ferric chloride reagent $(\mathrm{Wu}, 1964)$ was added. The mixture was centrifuged at $1000 \times g$ for $10 \mathrm{~min}$. The supernatant fluid was read at 525 $\mathrm{nm}$. In some experiments, $100 \mu \mathrm{M}$ iodoacetamide was added to the reaction mixture to see if the enzyme activity in rat intestine would be inhibited as in guinea pig liver (Folk and Cole, 1966).

Protein was determined according to the procedure of Lowry et al. (1951) with bovine serum albumin as standard.

\section{Binding of nitrofurantoin metabolite to protein}

These experiments were done first with ${ }^{14} \mathrm{C}$-nitrofurantoin under anaerobic conditions. The incubation mixture consisted of the same components as used in both nitroreductase and transglutaminase assays, except that hydroxylamine and CBZ- 
L-glutaminylglycine were omitted, the final $\mathrm{pH}$ being 7.2. These components were $0.16 \mathrm{mM}$ nitrofurantoin, $3.8 \mathrm{mM}$ glucose-6-phosphate, $0.67 \mathrm{mM}$ $\mathrm{MgCl}_{2}, 0.12 \mathrm{mM} \mathrm{NADP}{ }^{+}, 5 \mathrm{mM} \mathrm{CaCl}, 10 \mathrm{mM}$ glutathione, $25 \mathrm{mM}$ potassium phosphate buffer, $\mathrm{pH} 7.4$, and tissue extract containing $3.0-21.0 \mathrm{mg}$ protein per $\mathrm{ml}$ of the reaction mixture. In addition, $4 \mathrm{mg}$ bovine serum albumin was added per $\mathrm{ml}$ of reaction mixture to assure that sufficient protein would be available for coupling to drug metabolites, and the initial radioactivity in the reaction mixture was adjusted to about $45000 \mathrm{cpm} / \mathrm{ml}$. Incubation was done at $37^{\circ} \mathrm{C}$ for $30 \mathrm{~min}$. At the end of incubation, trichloroacetic acid was added to a final concentration of $10 \%$. The precipitate was washed repeatedly with $3 \%$ trichloroacetic acid until the washings contained no significant radioactivity above the background. The precipitate was dissolved in $1 \mathrm{~N} \mathrm{NaOH}$ for counting in a Packard liquid scintillation spectrometer $(45 \%$ counting efficiency). Incubation mixtures with extract inactivated for $20-30 \mathrm{~min}$ at $50^{\circ} \mathrm{C}$ served as controls. In a second series of experiments, protein-bound nitrofurantoin metabolite was prepared with unlabeled nitrofurantoin. After the trichloroacetic acid precipitate was dissolved in $\mathrm{NaOH}$, the protein solution was dialyzed against saline, concentrated if necessary, and used for immunization.

\section{Immunization of rabbits}

The protein conjugate of nitrofurantoin metabolite prepared with rat small intestine extract was used to immunize 2 rabbits. A concentrate of the conjugate was mixed with Freund's complete adjuvant and injected intradermally at multiple sites on the back of the animals. One month later, a booster injection in Freund's incomplete adjuvant was given similarly. The initial and booster injections each contained the equivalent of $50 \mu \mathrm{g}$ of bound nitrofurantoin.

\section{Radioimmunoassay}

The assay was carried out as follows: $245 \mu \mathrm{l}$ of phosphate buffered saline $(0.14 \mathrm{M} \mathrm{NaCl}, 0.01 \mathrm{M}$ phosphate buffer, pH 7.2, $0.02 \%$ sodium azide, and
$1 \%$ bovine serum albumin) containing about 4000 cpm of ${ }^{14} \mathrm{C}$-nitrofurantoin in $1.2 \mathrm{nmol}$ was incubated with $5 \mu$ l of rabbit serum (control or immunized) for $2 \mathrm{~h}$ at $4^{\circ} \mathrm{C}$. When necessary, serum samples from immunized animals were diluted with control serum. After the incubation, $350 \mu \mathrm{l}$ of phosphate buffered saline containing $100 \mu \mathrm{l}$ of goat antirabbit immunoglobulin serum titered to the equivalence point was added, mixed and kept at $4^{\circ} \mathrm{C}$ for $18 \mathrm{~h}$. The mixture was centrifuged at $2000 \times g$ for $10 \mathrm{~min}$, and $500 \mu \mathrm{l}$ of the supernatant fluid was used for counting.

\section{Results and Discussion}

Table I shows the results of the tests for nitroreductase activity in rat liver and small intestine. The activity was higher in the liver than in the small intestine. Aerobic conditions inhibited greatly the reductase activity. Since Batteli et al. (1972) have reported that rat small intestine contained higher activity of xanthine oxidase than other rat tissues, we used hypoxanthine as cofactor to measure nitroreductase activity in small intestine and obtained similar results to those with NADPH. Hence, nitrofurantoin was also a substrate of xanthine oxidase in small intestine as it was in liver (Boyd et al., 1979; Wang et al., 1974).

As mentioned above, transglutaminase activity has been shown to be involved in the transfer of some drugs, such as hydralazine, to protein as a mechanism for drug allergy. Certain hydroxylamines can also serve as substrates of transglutaminase, and this reaction has been utilized in the colorimetric assay of the enzyme activity. Table II shows the enzyme activity in small intestine and cecum as compared with that in liver. The latter had activity 10-15 times higher than the intestines, but the intestinal activity was significant and also susceptible to iodoacetamide inhibition, as is the liver enzyme.

We then proceeded to study binding of nitrofurantoin metabolite to protein in preparation of the complex for subsequent immunization. Essentially, 
TABLE I

Nitroreductase activity in rat liver and small intestine

\begin{tabular}{|c|c|c|c|}
\hline Extract & Cofactor & Conditions $^{\mathrm{a}}$ & $\begin{array}{l}\text { Activity }^{\mathrm{b}} \\
\text { (nmol/mg protein/min) }\end{array}$ \\
\hline \multirow[t]{2}{*}{ Liver } & NADPH & Anaerobic & $2.7 \pm 0.2$ \\
\hline & & Aerobic & $0.46 \pm 0.12$ \\
\hline \multirow[t]{3}{*}{ Small intestine } & NADPH & Anaerobic & $2.0 \pm 0.1$ \\
\hline & & Aerobic & $0.32 \pm 0.07$ \\
\hline & Hypoxanthine & Anaerobic & $1.8 \pm 0.2$ \\
\hline
\end{tabular}

a The reaction mixture contained $0.16 \mathrm{mM}$ nitrofurantoin, $0.67 \mathrm{mM} \mathrm{MgCl}, 3.8 \mathrm{mM}$ glucose-6-phosphate, $0.12 \mathrm{mM} \mathrm{NADP}+, 25 \mathrm{mM}$ potassium phosphate buffer, $\mathrm{pH} 7.4$, and about $20 \mathrm{mg}$ tissue per $\mathrm{ml}$. When hypoxanthine $(0.20 \mathrm{mM})$ was used, glucose-6-phosphate and $\mathrm{NADP}^{+}$were omitted. Incubation was done under $\mathrm{N}_{2}$ or air at $37^{\circ} \mathrm{C}$ for $20 \mathrm{~min}$.

b Assessed by the decrease in nitrofurantoin present as measured by a modification of the hyamine assay of Mattok et al. (1970).

the conditions for assaying nitroreductase and transglutaminase activities were combined. Since the preparation of the highest yield of the complex rather than the measurement of initial rates of the reactions was our goal, we allowed the incubation to proceed for a longer period of time than dictated by the initial rate measurement. The results of several experiments with ${ }^{14} \mathrm{C}$-nitrofurantoin are summarized in Table III. Increasing the protein concentration in the reaction mixture increased proportionally the level of bound radioactivity so

\section{TABLE II}

Transglutaminase activity in rat liver and intestines ${ }^{\mathrm{a}}$

\begin{tabular}{lll}
\hline Extract & $\begin{array}{l}\text { Iodoacetamide } \\
(100 \mu \mathrm{M})\end{array}$ & $\begin{array}{l}\text { Activity } \\
\text { (nmol/mg } \\
\text { protein/min) }\end{array}$ \\
\hline Liver & & $35 \pm 3.0$ \\
Small intestine & - & $0.72 \pm 0.04$ \\
& + & $2.5 \pm 0.3$ \\
Cecum & - & $0.10 \pm 0.01$ \\
& + & $3.7 \pm 0.2$ \\
& - & $0.13 \pm 0.01$
\end{tabular}

a The reaction mixture contained $5 \mathrm{mM} \mathrm{CaCl}_{2}, 100 \mathrm{mM}$ hydroxylamine hydrochloride, $10 \mathrm{mM}$ glutathione, $30 \mathrm{mM}$ CBZ-L-glutaminylglycine, $0.1 \mathrm{M}$ Tris acetate buffer, $\mathrm{pH} 6.0$, and about $50 \mathrm{mg}$ tissue per ml. Incubation was done at $37^{\circ} \mathrm{C}$ for $20 \mathrm{~min}$. that the level of radioactivity bound per mg protein remained nearly constant, suggesting that the binding takes place at specific, saturable sites of the protein. The average was $50 \mathrm{nmol}$ of the labeled metabolite bound per mg protein. When parallel experiments with unlabeled nitrofurantoin were done, we assumed a similar level of binding had occurred,

\section{TABLE III}

Binding of nitrofurantoin metabolite to protein in rat small intestine $^{\mathrm{a}}$

\begin{tabular}{llll}
$\begin{array}{l}\text { Experiment } \\
\text { number }\end{array}$ & $\begin{array}{l}\text { Protein in } \\
\text { reaction } \\
\text { mixture } \\
(\mathrm{mg} / \mathrm{ml})\end{array}$ & $\begin{array}{l}{ }^{14} \mathrm{C}-\mathrm{Nitro}- \\
\text { furantoin } \\
\text { in reaction } \\
\text { mixture } \\
(\mathrm{cpm} / \mathrm{ml})\end{array}$ & $\begin{array}{l}{ }^{14} \mathrm{C}- \\
\text { Metabolite } \\
\text { bound to } \\
\text { protein } \\
(\mathrm{nmol} / \mathrm{mg})\end{array}$ \\
\hline 1 & & 37240 & 51 \\
2 & 7.5 & 43500 & 54 \\
3 & 15.5 & 42730 & 42 \\
4 & 12.7 & 49480 & 54
\end{tabular}

a The reaction mixture contained $0.16 \mathrm{mM}$ nitrofurantoin with radioactivity adjusted to $35000-50000 \mathrm{cpm} / \mathrm{ml}, 3.8 \mathrm{mM}$ glucose-6-phosphate, $0.67 \mathrm{mM} \mathrm{MgCl}_{2}, 0.12 \mathrm{mM} \mathrm{NADP}^{+}, 5 \mathrm{mM}$ $\mathrm{CaCl}_{2}, 10 \mathrm{mM}$ glutathione, $25 \mathrm{mM}$ potassium phosphate buffer, $\mathrm{pH} 7.4$, bovine serum albumin $4 \mathrm{mg} / \mathrm{ml}$, and tissue extract containing 3.0-18.0 mg protein per $\mathrm{ml}$. Each experiment was run for $30 \mathrm{~min}$ in duplicate. Deviations from the respective means were less than $10 \%$.

b Measured on the repeatedly washed trichloroacetic acid precipitate redissolved in $\mathrm{NaOH}$. 
and $50 \mathrm{nmol} / \mathrm{mg}$ protein was used for calculating the dose for immunization.

Although transglutaminase activity is present in small intestine, its role in the binding of nitrofurantoin metabolite to protein is uncertain. Reduction of the $-\mathrm{NO}_{2}$ group of nitrofurantoin may lead to more than one reduction product, such as the $-\mathrm{NH}_{2}$ and $-\mathrm{NHOH}$ derivatives (Jonen et al., 1980). These derivatives are possible substrates of transglutaminase. However, binding to protein of 5-nitrofurans has been shown to occur with purified milk xanthine oxidase (Wang et al., 1974). Hence, transglutaminase activity is not essential to the binding. In our labeled experiments, we were also unable to demonstrate a significant lowering of the binding with iodoacetamide. However, the low degree of binding observed in the control experiments with inactivated tissue extract indicates that some kind of enzymatic activity is required. In addition to enzymatic degradation of nitrofurantoin, it is very likely that enzymatic activity is required for most of the coupling with protein since none of the known nitrofurontoin metabolites which could generate antibodies reactive with ${ }^{14} \mathrm{C}$-nitrofurantoin is sufficiently reactive to couple covalently to protein without enzymatic intervention.

Fig. 1 shows the antibody titer against nitrofur-

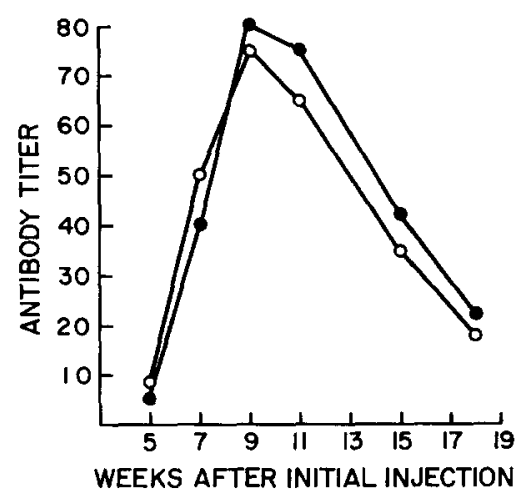

Fig. 1. Antibody formation in rabbits immunized with nitrofurantoin metabolite-protein conjugate prepared from rat intestine extract. The ordinate shows the serum dilution required for $50 \%$ precipitation of labeled nitrofurantoin in a double antibody type radioimmunoassay. Initial immunization was with $50 \mu \mathrm{g}$ bound nitrofurantoin in complete Freund's adjuvant, and the same antigen dose was injected one month later in incomplete Freund's adjuvant. antoin in 2 rabbits immunized with protein conjugate of nitrofurantoin metabolite formed in rat small intestine extract. The highest titer (1:75-80) was obtained about 9-11 weeks after the initial injection. Control animals receiving free nitrofurantoin in the same dosage as the experimental animals showed no antibody titer (data not shown). The successful demonstration of the antihapten antibody formation in these experiments implies that an extrahepatic tissue, such as small intestine, can metabolize an orally administered drug and conjugate its metabolite(s) to protein. This conjugate may stimulate antibody formation against the drug hapten, thereby providing a mechanism for drug allergy.

The fact that the drug hapten -protein conjugation observed here appears to be enzymatically mediated is worthy of further comment. Detailed investigations of penicillin allergy have emphasized the generation of reactive drug metabolites which can covalently bind to protein carriers. Accordingly it has been widely presumed that a similar mechanism accounts for the development of allergenicity to other drugs. However, in the 25 years since the mechanism of penicillin allergy was worked out (Parker et al., 1961; Levine and Ovary, 1961), there have been very few instances in which reactive metabolites have been found to account for immunologically mediated reactions to other drugs. Thus, it is attractive to suggest that the binding to protein of more stable drugs or drug metabolites by endogenous enzymes is a potential mechanism of drug allergy which merits consideration in studying reactions to other drugs.

\section{Acknowledgments}

This work was supported in part by a grant (GM 32591) from the National Institutes of Health, U.S. Public Health Service.

\section{References}

Aufrere MB, Hoener B, Vore M (1978) Reductive metabolism of nitrofurantoin in the rat. Drug Metab Disp 6:403. 
Batteli MG, Della Corte E, Stirpe F (1972) Xanthine oxidase type $D$ (dehydrogenase) in the intestine and other organs of the rat. Biochem $J 126: 747$.

Boyd MR, Stiko AW, Sasame HA (1979) Metabolic activation of nitrofurantoin - possible implications for carcinogenesis. Biochem Pharmacol 28:601.

Buxman MM (1979) The role of enzymatic coupling of drugs to proteins in induction of drug specific antibodies. $J$ Invest Dermatol 73:255.

Connellan JM, Chung SI, Whetzel NK, Bradley LM, Folk JE (1971) Structural properties of guinea pig liver transglutaminase. $J$ Biol Chem 246:1093.

Eisen HN (1959) Cellular and Humoral Aspects of the Hypersensitive States. New York: Paul B Hoeber.

Folk JE, Cole PW (1966) Mechanism of action of guinea pig liver transglutaminase. I. Purification and properties of the enzyme: Identification of a functional cysteine essential for activity. $J$ Biol Chem 241:5518.

Hoener B, Krueger TR (1984) Disposition of nitrofurantoin and nitrofurazone in the isolated perfused rat kidney. $J$ Pharm Sci 73:1669.

Holmberg L, Boman G, Bottiger LE, Eriksson B, Spross R, Wessling A (1980). Adverse reaction to nitrofurantoin. Analysis of 931 reports. Am J Med 69:733.

Jonen HG, Oesch F, Platt KL (1980) 4-Hydroxylation of nitrofurantoin in the rat. A 3-methylcholanthrene-inducible pathway of a relatively nontoxic compound. Drug Metab Disp $8: 446$.

Landsteiner K (1936) The Specificity of Serological Reactions. Springfield, IL: Charles C. Thomas. pp. 100-147.
Levine BB, Ovary $Z$ (1961) Studies on the mechanisms of the formation of the penicillin antigen. $J$ Exp Med 114:875.

Lorand L, Campbell LK, Robertson JB (1972) Enzymatic coupling of isoniazid to proteins. Biochemistry 11:434.

Lowry OH, Rosebrough NJ, Farr AL, Randall RJ (1951) Protein measurement with the Folin phenol reagent. $J$ Biol Chem 193:265.

Mattok GL, McGilveray IJ, Charette C (1970) Improved nitromethane-hyamine method for the chemical determination of nitrofurantoin in whole blood. Clin Chem 16:820.

Moreno SNJ, Mason RP, Docampo R (1984) Reduction of nifurtimox and nitrofurantoin to free radical metabolites by rat liver mitochondria. $J$ Biol Chem 259:6298.

Parker CW (1979) Drug Allergy. In Burger's Medicinal Chemistry, 4th Edn. Ed. ME Wolff. New York: John Wiley \& Sons, pp. 422-426.

Parker CW (1980) Drug Allergy. In Clinical Immunology. Ed. CW Parker. Philadelphia: W.B. Saunders, pp. 1221.

Parker CW, deWeck AL, Kern M, Eisen HN (1961) Preparation and some properties of penicillenic acid derivatives relevant to penicillin hypersensitivity. $J$ Exp Med 115:803.

Wang CY, Behrens BC, Ichikawa M, Bryan GT (1974) Nitroreduction of 5-nitrofuran derivatives by rat liver xanthine oxidase and reduced nicotinamide adenine dinucleotide phosphate cytochrome $c$ reductase. Biochem Pharmacol 23:3395.

Wu C (1964) Glutamine synthetase. IV. Its formation in rat liver following partial hepatectomy and during repletion. Arch Biochem Biophys 106:402. 